\title{
Corticosteroids for COVID-19: worth it or not?
}

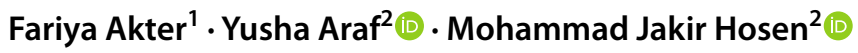

Received: 22 July 2021 / Accepted: 17 September 2021 / Published online: 13 October 2021

(c) The Author(s), under exclusive licence to Springer Nature B.V. 2021

\begin{abstract}
Pathogenesis of severe acute respiratory syndrome coronavirus 2 (SARS-CoV-2) induced COVID-19 implied the presence of excessive proinflammatory cytokines and chemokines in patients causing significant morbidity and mortality. To diminish systemic hyper inflammation, a few physicians and researchers have utilized corticosteroids. Corticosteroid implementation has increased after the publication of interim guidelines regarding corticosteroid use in COVID-19 patients by WHO, despite the remaining controversies regarding long-term side effects and disease progression capability of corticosteroids. In different studies, the implementation of corticosteroids on COVID-19 patients revealed controversial results, which require further intensive research. This review will present the current outcomes and possibilities of using corticosteroids to treat COVID-19 patients.
\end{abstract}

Keywords COVID-19 $\cdot$ Corticosteroids $\cdot$ Immunosuppression $\cdot$ Side-effects $\cdot$ Inflammatory-molecules $\cdot$ Cytokine storm

\section{Introduction}

COVID-19 pandemic has emerged as a significant global health threat since December 2019 [1], to this report affected $221,648,869$ people, and among them, 4,582,338 died [2]. The clinical spectrum and severity of this disease are very diverse. Patients can be ranged from non-symptomatic to have only a few mild symptoms or severe pneumonia, acute respiratory distress, multi-organ failure, ultimately leading to death [3-6]. Severe acute respiratory syndrome coronavirus 2 (SARS-CoV-2) is the causative agent of COVID-19 that affects multiple organs of humans by binding its spike glycoprotein to the angiotensin-converting enzyme 2 (ACE2) receptor present in vascular endothelial cells lungs, heart, brain, kidneys, intestine, liver, pharynx [7-10]. Thus, the local immune response triggers and enforces inflammatory molecules, including macrophages, monocytes, cytokines,

Mohammad Jakir Hosen

jakir-gen@sust.edu

Yusha Araf

yusha.araf@gmail.com

1 Biotechnology Program, Department of Mathematics and Natural Sciences, Brac University, Dhaka, Bangladesh

2 Department of Genetic Engineering and Biotechnology, School of Life Sciences, Shahjalal University of Science and Technology, Sylhet, Bangladesh prime adaptive T and B cells [11]. Moreover, SARS-CoV-2 is a cytopathic virus that causes pyroptosis, progressive systemic inflammation, low lymphocyte, and high neutrophil counts [12-14]. This systemic inflammation releases cytokines and chemokines by the immune cells, creating cytokine storms [15]. COVID-19 patient's report shows high levels of interleukins (such as IL-1 $\beta$, IL-1RA, IL-6, IL-8, IL-9, IL-10, IL-17), vascular endothelial growth factor, macrophage inflammatory proteins, tumor necrosis factor-alpha, other proinflammatory chemokines, cytokines, and signaling proteins presence in blood. Cytokine storm elevates the risk of developing acute respiratory distress syndrome (ARDS) along with multiple organ failure [16]. Corticosteroids (CSs) are among the most widely used anti-inflammatory drugs for treating inflammatory and immune diseases, including rheumatoid arthritis, systemic lupus erythematosus, asthma [17, 18]. CSs influence multiple signal transduction pathways to induce anti-inflammatory effects by switching off multiple activated inflammatory genes and activating several antiinflammatory genes that increase the degradation of mRNA encoding specific inflammatory proteins [18].

In September 2020, the World Health Organization (WHO) had recommended the use of CSs (such as dexamethasone, hydrocortisone, or prednisone) to treat severe and critically ill COVID-19 patients [19]. However, the high availability of CSs is encouraging physicians to use these medicines randomly to treat COVID-19 patients, 
especially in complications like inflammation and cytokine storms [15]. Studies demonstrate that inappropriate CSs dose increases the risk of developing thrombosis and venous thromboembolism (VTE) in COVID-19 patients. Additionally, CSs therapy can cause various moderate and longterm adverse effects, including increased insulin resistance, increased cardiovascular risk, the risk of bacterial infection, glucose metabolism disorder, increased risk of thrombotic and thromboembolic complications, super-infection, dermatological complications, complications in metabolism, musculoskeletal disease, nervous system, ophthalmic complications, reproductive system, and allergic reaction, etc. [15, 20-24]. The motive of this review is to analyze the result of CSs therapy on COVID-19 patients from different metaanalyses, cohorts, and case studies to understand the longterm effect of CS therapy on COVID-19 recovered patients. This review will open avenues to correct the use of CSs in COVID-19 treatment and proper management of patients.

\section{Immunosuppression mechanism of corticosteroid}

The primary role of CSs is to reverse the inflammatory genes. Moreover, CSs can also be helpful in the synthesis of anti-inflammatory proteins and post-genomic effects [18]. The immunosuppression mechanism of CSs is induced with the help of glucocorticoid receptor (GR) as it can repress the activity of NF- $\mathrm{KB}$ (nuclear factor kappa light chain enhancer of activated B cells), AP-1 (Activator Protein-1) along with immunomodulatory transcription factors. After binding with CSs, GR comes into the nucleus and binds with the subunits (p50 and p65) of NF- $\kappa B$ and transrepresses the subunits to help in the inflammatory protein production. However, it induces the production of NF- $\kappa \mathrm{B}$ inhibitor, I $\mathrm{I} \mathrm{B} \alpha$ (nuclear factor of kappa light polypeptide gene enhancer in B-cells inhibitor, alpha) that restricts the production of Inflammatory molecules [25].

Moreover, GR also inhibits the activity of AP-1 by binding on the AP-1 binding site of TRE (12-O-Tetradecanoylphorbol-13-acetate (TPA) response element). The model mechanism manifested that AP-1 and GR compete to add the required co-factor, and GR occupies TRE. Thus, AP- 1 is unable to go to TIC for transcription initiation. As the binding gets interrupted, AP-1 cannot start traction of inflammatory proteins that in turn cause immunosuppression [26]. The mechanisms are summarized in Fig. 1.

\section{Outcomes of corticosteroids treatment in COVID-19 patients}

Like SARS and MERS, CSs have been utilized widely in COVID-19 treatment [6, 27-29]. As COVID-19 is associated with systemic hyper inflammation and complications like ARDS and pneumonia, researchers thought of CSs that can be beneficial [30-33]. However, the efficiency and safety of corticosteroids in treating severe infections are a neverending debate between researchers [34-36].

Different observational studies and randomized controlled trials (RCTs) have confirmed the beneficial effect of corticosteroids including, reduced mortality rate and the requirement of mechanical ventilation [37]. Moreover, a retrospective study reported that corticosteroids in severe COVID-19 pneumonia help to decrease the risk of orotracheal intubation and ventilation in the ICU [38]. In addition, an observational study reported that CSs on COVID-19 patients are protective to ICU patients but found ineffective on non-ICU patients. However, the study could not perceive the effect of CSs on COVID-19 patients' mortality [39].

The application of CSs also showed a shorter fever duration and improved oxygen saturation in a COVID-19 patient cohort compared to control [40]. Meta-analysis and RCTs also revealed that the application of CSs in critically ill COVID-19 patients' results decrease the mortality rate [41]. All the positive outcomes of CS utilization on COVID-19 patients are summarized in Table 1.

Application of CSs in a different cohort of hospitalized COVID-19 patients revealed a heterogeneous result. Ding et al., found no correlation between viral clearance duration and CSs in hospitalized mild COVID-19 patients [42]. Similarly, a meta-analysis of wang et al. observed delayed viral clearance in hospitalized COVID-19 patients after using CSs along with and no-effective improvement [43]. This indicates longer hospital admission of COVID-19 patients could be caused by CSs. Whereas, CSs have been observed to be beneficial in decreasing the rate of mortality and ICU admission for hospitalized patients with COVID-19 pneumonia [44], especially to the hospitalized COVID-19 patients who are receiving either invasive mechanical ventilation or oxygen [45]. In this case, the critical COVID-19 patients need to stay in the hospital for a shorter period as CSs help to reduce other complications.

Though CSs treatment positively impacted COVID-19 patients, it is also reported that unoptimized doses could be dangerous. In addition, CSs treatment might cause delayed viral clearance, secondary infections, increase antibiotic use, and further complications [31-33]. An in vivo study on pigs revealed that dexamethasone is effective only in the acute phase, and rapid replication of the virus was observed after its prolonged use [46]. In a separate study, Chu et al. 


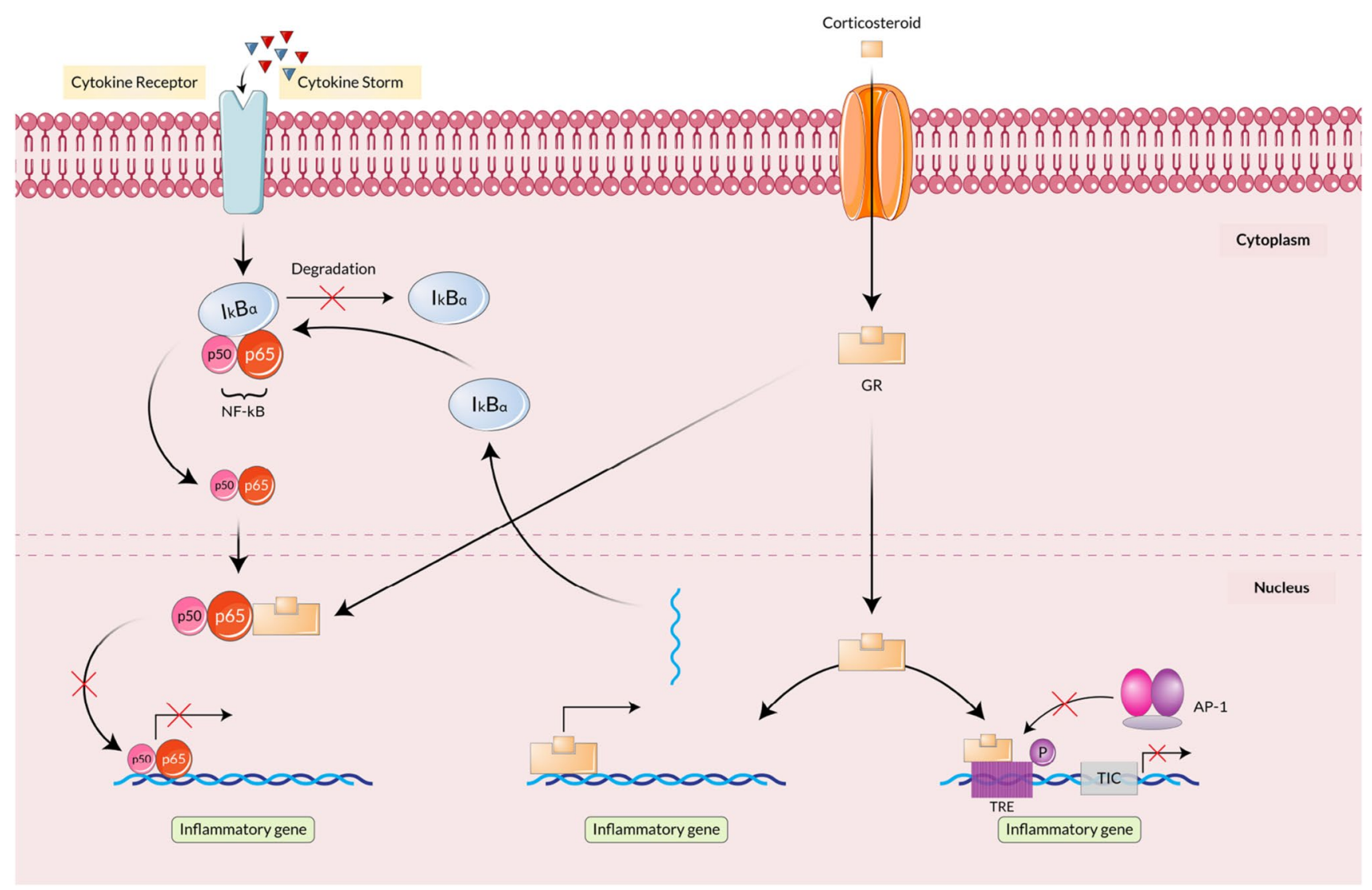

Fig. 1 Immunosuppression mechanism of Corticosteroids. Cytokine storm leads to the binding of cytokine in the cytokine receptor of the cell membrane, which initiates NF- $\mathrm{\kappa B}$ production in the cytoplasm. $\mathrm{NF}-\mathrm{\kappa B}$ enters the nucleus to produce inflammatory proteins that get inhibited after corticosteroid implementation. Corticosteroid attaches to GR (Glucocorticoid Receptor) and transfers into the nucleus where it binds to the subunits of NF- $\mathrm{KB}$ and inhibits inflammatory protein production. GR also inhibits AP-1 from producing inflammatory proteins by attaching to the active site of TRE

Table 1 List of available studies that determined the positive effects of CSs on COVID-19 patients

\begin{tabular}{|c|c|c|c|c|}
\hline Types of study & Country of study & Sample Size & Outcome & Reference \\
\hline Meta-analysis & $\begin{array}{l}\text { China, Europe, North America, South America, } \\
\text { Multi-continental }\end{array}$ & 20,197 & $\begin{array}{l}\text { Lower mortality rate } \\
\text { Less mechanical ventilation requirement } \\
\text { Delayed viral clearance } \\
\text { Increased secondary Infection }\end{array}$ & [37] \\
\hline Retrospective study & France & 70 & $\begin{array}{l}\text { Lower risk of orotracheal intubation and } \\
\text { ventilation in ICU } \\
\text { Prevents worsening of COVID-19 severe } \\
\text { pneumonia }\end{array}$ & {$[38]$} \\
\hline Clinical analysis & China & 46 & $\begin{array}{l}\text { Improved hypoxia and fever } \\
\text { Shortened disease course }\end{array}$ & [40] \\
\hline Meta-analysis & $\begin{array}{l}\text { Austria, Spain, Brazil, UK, US, China, Canada, New- } \\
\text { Zealand, Denmark, France, European Union, }\end{array}$ & 1703 & Lower mortality rate & {$[41]$} \\
\hline
\end{tabular}

manifested that corticosteroid therapy banded together with immunity suppression, increased viral load, and delayed viral clearance from the patient [47]. Surprisingly, Zha et al. have not found any significant change between CSs treated and untreated COVID-19 patients but CSs are found to be effective in improving compliances and hypoxia in ARDS patients that in turn reduce ICU admission chance [48, 49]. Remarkably, several studies, including meta-analysis, found a higher mortality risk in the CSs treated COVID-19 group, extended stay in the hospital, increased viral shedding, prolonged periods of symptoms compared to the control [48-53]. In a comparative study of 34 patients with severe 
coronavirus pneumonia, patients treated with CS showed an intense disease course [15]. COVID-19 patients treated with high-dose (1000 mg methylprednisolone for 3 days and dexamethasone $8 \mathrm{mg}$ for another 3-5 days) CS demonstrated that an increased glucose level (in 35.3\% patients) and D-dimer level together with increased risk of VTE [54], thrombosis [55], increased neutrophil [56], increased NLR (indicates the activation of chronic inflammation) [57, 58], and autoimmune endothelial inflammation (delayed lung airway recovery) $[15,59]$. The rate of secondary infections has been increasing lately, as demonstrated black fungus infection in CSs treated COVID-19 patients (85\%) in India [60-62]. Thus, it might be critical to use of CSs therapy in severe COVID-19 patients. The negative effects on COVID19 patients after utilizing CSs are summarized in Table 2.

\section{Adverse effect of corticosteroids to mediate different disease induction}

CSs are not only well known for treating different severe diseased patients but also reputed for serious side effects. These include osteoporosis, hypertension, glaucoma, skeletal muscle atrophy, fluid retention, gastric ulcer disease, psychiatric disease, insulin resistance, myopathy, osteonecrosis, etc. [61]. Some of the effects along with mechanisms are described below:

\section{Diabetes mellitus}

The onset of hyperglycemia or diabetes mellitus (DM) is most often associated with CS [62]. Increased blood glucose level was reported in many patients (without preexisting diabetes) treated with CS therapy. However, the case is not always straightforward [63]. One of the most concerning factors for CS-induced diabetes mellitus is the dose of CS. A higher dose of CS (dexamethasone $>4 \mathrm{mg}$, hydrocortisone $>50 \mathrm{mg}$, prednisolone $>20 \mathrm{mg}$ ) can easily lead to severe complications [64]. A meta-analysis found that the chance of CS-induced hyperglycemia and diabetes were $32.3 \%$ and $18.6 \%$, respectively [65]. Various factors are related to the initiation of diabetes after the introduction of CS, which includes impairment of multiple pathways including $\beta$ cell dysfunction [66], insulin resistance of tissues that can affect glucose metabolism [67, 68], reduction of peripheral glucose uptake by muscle and adipose tissues that increases the blood glucose level [67, 69], activation of genes involved in the hepatic metabolism of carbohydrates results in increased gluconeogenesis, inhibition of pancreatic $\beta$-cells from production and secretion of insulin [70, 71].

\section{Myopathy}

CSs can directly affect the muscle by decreasing protein synthesis while increasing the protein catabolism, leading to muscle atrophy [72]. There are various mechanisms via which CSs initiates the catabolic effects. One mechanism is inhibiting amino acid transportation in the muscles, affecting protein synthesis [73]. Moreover, activation of cellular proteolytic systems such as the ubiquitin-proteasome system, lysosomal system, and calcium-dependent system also result in extensive muscle degradation [74]. Inhibition of muscle growth factor IGF-1, stimulating muscle production of myostatin, is also responsible for myopathy. As IGF-1 is inhibited, it suppressed muscle development and is unable to decrease apoptosis and proteolysis.

On the contrary, increased myostatin downregulate protein synthesis, proliferation, and differentiation of satellite cells [72]. Additionally, mitochondrial dysfunction also leads to CS-induced myopathy [75]. Generally, CS-induced myopathy is mainly seen in ICU patients as they have been given CSs in a higher dose and for a more extended period, and they are suffering from nutritional deficiency [72].

Table 2 List of available studies that determined the negative effects of CSs on COVID-19 patients

\begin{tabular}{|c|c|c|c|c|}
\hline Types of study & Country of study & Sample size & Outcome & Reference \\
\hline Observational study & China & 31 & $\begin{array}{l}\text { Higher inflammation index } \\
\text { More abnormalities on the chest } \\
\text { Did not influence virus clearance time } \\
\text { No change in hospital length of stay }\end{array}$ & [48] \\
\hline Observational study & Italy & 1444 & $\begin{array}{l}\text { More hypoxic } \\
\text { Higher inflammation markers } \\
\text { Severe lymphocytopenia }\end{array}$ & [49] \\
\hline Meta-analysis & China, Korea, Spain, France, Italy & 9594 & $\begin{array}{l}\text { Higher mortality risk } \\
\text { Delayed viral clearance } \\
\text { Longer hospital length of stay }\end{array}$ & {$[50]$} \\
\hline Meta-analysis & USA, Spain, China, New York, UK, Italy & 15,754 & $\begin{array}{l}\text { Increased mortality rate } \\
\text { Longer hospital length of stay } \\
\text { Delayed viral clearance }\end{array}$ & {$[51]$} \\
\hline
\end{tabular}




\section{Osteonecrosis}

Osteonecrosis of the femoral head (ONFH) is related to several risk factors. Random CS use for a longer period is one of the significant factors of ONFH [76]. Recovered patients from previous SARS and MARS outbreaks had experienced avascular necrosis due to CS usage [76]. Moreover, steroidinduced decrement of local blood flow or lipid emboli and lipid-loaded fibrin-platelet thrombi might be a reason behind it [77]. $24.1 \%$ of recovered SARS patients treated with CS, was found with steroid-induced ONHF [78]. Remarkably, the use of dexamethasone was found to cause skeletal complications more than other CSs, which is a matter of concern as dexamethasone has been utilized for RCTs [79]. An increment of marrow fat ratio, which causes intra-osseous pressure and decrement in bone perfusion, can cause CS-induced osteonecrosis [80].

\section{Associated side effects of different corticosteroids}

Along with some common difficulties, each of the CS has some specific side effects. A broad spectrum of side effects has been identified, including fluid retention, behavioral and mode alteration, weight gain, high blood pressure, increased appetite, etc., and these complications are divided into twelve categories [20]. In COVID-19 patients, despite reducing complications, CS can cause long-term complications. Possible side effects of different CSs in COVID-19 treatment are briefly described below-

\section{Dexamethasone}

The most common risks of dexamethasone are hormonal imbalance, fluid retention, weight gain, anxiety, and disturbed sleep pattern, whereas the less common chances are hemorrhage, blurred vision, and eye disorder [81]. Increased risk of infection, especially fungal infections, delayed wound healing, joint avascular necrosis, gastrointestinal bleeding and perforation, restlessness, flushing, nausea, and vomiting can happen after having it [20]. While implementing early short-course corticosteroids in hospitalized COVID-19 patients, hyperglycemia was observed [82]. Another concerning effect of dexamethasone is venous thromboembolism that increases clotting factor levels, fibrinogen, factor VII, VIII, IX, etc. [83]. A notable consequence of this CS in COVID-19 is reduced vascular permeability [84], hindrance of the mediators (maresins, lipoxins) activity [85].

\section{Hydrocortisone}

Hypertension is the most common cardiovascular complication of hydrocortisone use. Hyperglycemia, urinary tract infection, osteoporosis, epistaxis are some of the significant complications. After taking hydrocortisone treatment, different minor complications such as throat discomfort, dizziness, sleepiness, lack of appetite, sneezing, weight loss, infections, etc. can also occur [20]. The complete analysis of efficiency and safety of hydrocortisone was not done after having mild positive results of COVID-19 ARDS patients compared to the placebo group [86, 87]. In a case study of SARS patients, psychosis has been observed in the patients who were given a higher dose of hydrocortisone [88]. Moreover, a randomized control trial has manifested more significant viremia after treating moderately ill SARS patients with hydrocortisone than saline control [89].

\section{Prednisone}

Patients treated with prednisone were suffered from bone complications in the past along with fluid retention, heartburn, diarrhea, and nausea. Long-term prednisone consumption can induce many other complications such as myalgia, dermatologic event, insomnia, mood swing, joint swelling, depression, hot flashes, changes in fat distribution, etc. [20]. Recommendations such as lifestyle changes should be implemented to overcome prednisone-induced osteonecrosis [90].

\section{Recommendations to minimize the side effects of CSs treatment in COVID-19 patients}

CSs treatment in COVID-19 patients seems to have both beneficial and adverse effects. Thus, proper and safe uses of CSs are recommended.

The outcome of CSs among the treated COVID-19 patients is found to vary due to different doses. To mitigate the uncertainty, CSs could be used at a moderate dose for a shorter period [91]. A detailed medical history of the patients should be collected before treating with CSs to minimize CSs induced comorbidity. Management of sudden side-effects in patients must be planned while treating with CSs. A drug-drug interaction can play a vital role in COVID-19 treatment, especially critical patients; a board of expert physicians should be discussed before applying CSs. All the safety rules should maintain and proper time of treatment should follow to use CSs on COVID-19 patients. Short-term, high doses of CS influence higher mortality along with mechanical ventilation requirements. Thus, adequate management of the patients should take into account [92]. To assess the perfect time for dexamethasone 
implementation, measuring blood ferritin activity can be a lifesaver as it can be beneficial to identify cytokine storms [93].

Moreover, the pathophysiology of COVID-19 in different clinical stages needs to be marked to implement appropriate treatment in a specific situation [94]. CSs therapy can cause delayed virus clearance, as an alternative anti-cytokine agent should prefer [95, 96]. As COVID-19 patients have inadequate immunity and there is a possibility of reduced virus clearance after treating dexamethasone, the patient can be more immune-compromised if dexamethasone is used alone. Therefore, the utilization of dexamethasone accompanying intravenous immunoglobulin and beta interferon could be a better option [97]. Monitoring bone density is a must when patients are treated with CS, as CS usage is correlated with osteoporosis. Calcium and vitamin D supplements, along with CS therapy, will be beneficial to protect bones [17]. To treat the significant problem of COVID-19, ARDS supplements such as Vitamin D, Vitamin C, Mesenchymal stromal cell therapies, etc., can be given to minimize the long-term adverse effects [98]. Reproducibility of all the results from a different cohort of patients who have encountered other health care systems must be confirmed before going to any conclusion to make sure the ultimate effect of CSs therapy. Phenotypes and endotypes must be validated to get a reproducible result [98]. Routine follow-up of the recovered patients must be done for early detection of any unwanted adverse effect. Additional medications and physical therapy combined with pharmacotherapy can also be advised while CS therapy is ongoing to reduce the chance of long-term side effects [76].

\section{Conclusion}

COVID-19 pandemic has affected the health care system since 2019. Due to the unavailability of potential therapeutics and vaccines, the impendent effect of COVID-19 is still going on, and it has become the new normal. Besides, some of the countries are now observing the 2 nd and 3rd waves of this disease. COVID-19 shows heterogeneous symptoms in patients, and multiple factors, including genetic composition, association with comorbidity, host immunity, age, sex, etc., make this disease difficult to handle. Physicians and researchers are trying to develop the best treatment and management strategies, and WHO has already approved various vaccines without proper clinical trials to tackle the pandemic. CS was one of the alternatives approved by WHO as it has an anti-inflammatory and immune-suppressive role. But due to, variable findings of its treatment made physicians confused about using it. Moreover, possible side effects, including a recent black fungus outbreak in India in
CSs treated COVID patients, restrict its use. The research found that a proper dose is important to minimize the side effects. However, a mild dose of CS can be given to critically ill COVID-19 patients under the supervision of expert physicians to avoid CS-induced side effects. Thus, Extensive research is still needed considering different factors to determine whether to use CS therapy or not.

Acknowledgements The authors acknowledge the members of the Community of Biotechnology, Dhaka, Bangladesh, for their support during the preparation of the manuscript.

Author contributions YA conceived the study. FA, YA and MH designed the study. FA wrote the draft manuscript. FA, YA and $\mathrm{MH}$ carried out the revisions. All authors approved the final version of the manuscript.

Funding The authors received no funding from external sources.

Data availability Not applicable.

\section{Declarations}

Conflict of interest The authors declare that they have no known competing financial interests or personal relationships that could have appeared to influence the work reported in this paper.

Ethical approval Not applicable.

Consent to participate Not applicable.

Consent to publish Not applicable.

\section{References}

1. Liu Z, Li X, Fan G, Zhou F, Wang Y, Huang L, Yu J, Yang L, Shang L, Xie K, Xu J, Huang Z, Gu X, Li H, Zhang Y, Wang Y, Huang Z, Cao B (2021) Low-to-moderate dose corticosteroids treatment in hospitalized adults with COVID-19. Clin Microbiol Infect 27(1):112-117. https://doi.org/10.1016/j.cmi.2020.09.045

2. World Health Organization (2021) WHO coronavirus (COVID19) dashboard I WHO coronavirus (COVID-19) dashboard with vaccination data. https://covid19.who.int/

3. Du Y, Tu L, Zhu P, Mu M, Wang R, Yang P, Wang X, Hu C, Ping R, Hu P, Li T, Cao F, Chang C, Hu Q, Jin Y, Xu G (2020) Clinical features of 85 fatal cases of COVID-19 from Wuhan. A retrospective observational study. Am J Respir Crit Care Med 201(11):1372-1379. https://doi.org/10.1164/rccm. 202003-0543OC

4. Chen N, Zhou M, Dong X, Qu J, Gong F, Han Y, Qiu Y, Wang J, Liu Y, Wei Y, Xia J, Yu T, Zhang X, Zhang L (2020) Epidemiological and clinical characteristics of 99 cases of 2019 novel coronavirus pneumonia in Wuhan, China: a descriptive study. Lancet (London, England) 395(10223):507-513. https://doi.org/10.1016/ S0140-6736(20)30211-7

5. Wang Z, Yang B, Li Q, Wen L, Zhang R (2020) Clinical features of 69 cases with coronavirus disease 2019 in Wuhan, China. Clin Infect Dis 71(15):769-777. https://doi.org/10.1093/cid/ciaa272 
6. Wang D, Hu B, Hu C, Zhu F, Liu X, Zhang J, Wang B, Xiang H, Cheng Z, Xiong Y, Zhao Y, Li Y, Wang X, Peng Z (2020) Clinical characteristics of 138 hospitalized patients with 2019 novel coronavirus-infected pneumonia in Wuhan, China. JAMA 323(11):1061-1069. https://doi.org/10.1001/jama.2020.1585

7. Jain U (2020) Effect of COVID-19 on the organs. Cureus 12(8):e9540. https://doi.org/10.7759/cureus.9540

8. Meredith Wadman JC, Jocelyn Kaiser CM (2020) How does coronavirus kill? Clinicians trace a ferocious rampage through the body, from brain to toes. Science

9. Chen L, Li X, Chen M, Feng Y, Xiong C (2020) The ACE2 expression in human heart indicates new potential mechanism of heart injury among patients infected with SARS-CoV-2. Cardiovasc Res 116(6):1097-1100. https://doi.org/10.1093/cvr/cvaa078

10 Song H, Seddighzadeh B, Cooperberg MR, Huang FW (2020) Expression of ACE2, the SARS-CoV-2 receptor, and TMPRSS2 in prostate epithelial cells. bioRxiv. https://doi.org/10.1101/ 2020.04.24.056259

11. Tay MZ, Poh CM, Rénia L, MacAry PA, Ng L (2020) The trinity of COVID-19: immunity, inflammation and intervention. Nat Rev Immunol 20(6):363-374. https://doi.org/10.1038/ s41577-020-0311-8

12. Park WB, Kwon NJ, Choi SJ, Kang CK, Choe PG, Kim JY, Yun J, Lee GW, Seong MW, Kim NJ, Seo JS, Oh MD (2020) Virus isolation from the first patient with SARS-CoV-2 in Korea. J Korean Med Sci 35(7):e84. https://doi.org/10.3346/jkms.2020. 35.e84

13. Fink SL, Cookson BT (2005) Apoptosis, pyroptosis, and necrosis: mechanistic description of dead and dying eukaryotic cells. Infect Immun 73(4):1907-1916. https://doi.org/10.1128/IAI.73.4.19071916.2005

14 Yang M (2020) Cell pyroptosis, a potential pathogenic mechanism of 2019-nCoV infection. SSRN Electron J. https://doi.org/ $10.2139 /$ ssrn. 3527420

15. Mareev VY, Orlova YA, Pavlikova EP, Matskeplishvili ST, Krasnova TN, Malahov PS, Samokhodskaya LM, Mershina EA, Sinitsyn VE, Mareev YV, Kalinkin AL, Begrambekova YL, Kamalov AA (2020) Steroid pulse -therapy in patients With coronavirus pneumonia (COVID-19), systemic inflammation and risk of venous thrombosis and thromboembolism (WAYFARER Study). Kardiologiia 60(6):15-29. https://doi.org/10.18087/cardio.2020.6. n1226

16. Sun X, Wang T, Cai D, Hu Z, Chen J, Liao H, Zhi L, Wei H, Zhang Z, Qiu Y, Wang J, Wang A (2020) Cytokine storm intervention in the early stages of COVID-19 pneumonia. Cytokine Growth Factor Rev 53:38-42. https://doi.org/10.1016/j.cytogfr. 2020.04.002

17. Noreen S, Maqbool I, Madni A (2021) Dexamethasone: therapeutic potential, risks, and future projection during COVID-19 pandemic. Eur J Pharmacol 894:173854. https://doi.org/10.1016/j. ejphar.2021.173854

18. Barnes PJ (2006) How corticosteroids control inflammation: Quintiles prize lecture 2005. Br J Pharmacol 148(3):245-254. https:// doi.org/10.1038/sj.bjp.0706736

19. World Health Organization (2020) Corticosteroids for COVID-19: living guidance, 2 September 2020. World Health Organization

20. Langarizadeh MA, Ranjbar Tavakoli M, Abiri A, Ghasempour A, Rezaei M, Ameri A (2021) A review on function and side effects of systemic corticosteroids used in high-grade COVID-19 to prevent cytokine storms. EXCLI J 20:339-365. https://doi.org/ 10.17179/excli2020-3196

21. Darmon P, Dadoun F, Boullu-Ciocca S, Grino M, Alessi MC, Dutour A (2006) Insulin resistance induced by hydrocortisone is increased in patients with abdominal obesity. Am J Physiol Endocrinol Metab 291(5):E995-E1002. https://doi.org/10.1152/ ajpendo.00654.2005
22. Clore JN, Thurby-Hay L (2009) Glucocorticoid-induced hyperglycemia. Endocr Pract 15(5):469-474. https://doi.org/10.4158/ EP08331.RAR

23. Shono A, Mori S, Nakamura K, Yatomi A, Takada H, Tanaka H, Okano T, Morinobu A, Hirata KI (2019) Glucocorticoid-sensitive paroxysmal atrial fibrillation, sick sinus syndrome, and mitral regurgitation in a patient with malignant rheumatoid vasculitis. Intern Med (Tokyo, Japan) 58(21):3093-3098. https://doi.org/10. 2169/internalmedicine.3090-19

24. Johannesdottir SA, Horváth-Puhó E, Dekkers OM, Cannegieter SC, Jørgensen JO, Ehrenstein V, Vandenbroucke JP, Pedersen L, Sørensen HT (2013) Use of glucocorticoids and risk of venous thromboembolism: a nationwide population-based case-control study. JAMA Intern Med 173(9):743-752. https://doi.org/10. 1001/jamainternmed.2013.122

25. Coutinho AE, Chapman KE (2011) The anti-inflammatory and immunosuppressive effects of glucocorticoids, recent developments and mechanistic insights. Mol Cell Endocrinol 335(1):213. https://doi.org/10.1016/j.mce.2010.04.005

26. Didonato JA, Saatcioglu F, Karin M (1996) Molecular mechanisms of immunosuppression and anti-inflammatory activities by glucocorticoids. Am J Respir Crit Care Med 154(2 Pt 2):S11-S15. https://doi.org/10.1164/ajrccm/154.2_Pt_2.S11

27. Yang X, Yu Y, Xu J, Shu H, Xia J, Liu H, Wu Y, Zhang L, Yu Z, Fang M, Yu T, Wang Y, Pan S, Zou X, Yuan S, Shang Y (2020) Clinical course and outcomes of critically ill patients with SARSCoV-2 pneumonia in Wuhan, China: a single-centered, retrospective, observational study. Lancet Respir Med 8(5):475-481. https://doi.org/10.1016/S2213-2600(20)30079-5

28. Adams R, Christenson J, Petersen F, Beatty P (1999) Pre-emptive use of aerosolized ribavirin in the treatment of asymptomatic pediatric marrow transplant patients testing positive for RSV. Bone Marrow Transplant 24(6):661-664. https://doi.org/10.1038/sj. bmt.1701959

29. Huang C, Wang Y, Li X, Ren L, Zhao J, Hu Y, Zhang L, Fan G, Xu J, Gu X, Cheng Z, Yu T, Xia J, Wei Y, Wu W, Xie X, Yin W, Li H, Liu M, Xiao Y et al (2020) Clinical features of patients infected with 2019 novel coronavirus in Wuhan, China. Lancet (London, England) 395(10223):497-506. https://doi.org/10.1016/ S0140-6736(20)30183-5

30. Villar J, Confalonieri M, Pastores SM, Meduri GU (2020) Rationale for prolonged corticosteroid treatment in the acute respiratory distress syndrome caused by coronavirus disease 2019. Crit Care Explor 2(4):e0111. https://doi.org/10.1097/CCE.0000000000 000111

31. Villar J, Ferrando C, Martínez D, Ambrós A, Muñoz T, Soler JA, Aguilar G, Alba F, González-Higueras E, Conesa LA, MartínRodríguez C, Díaz-Domínguez FJ, Serna-Grande P, Rivas R, Ferreres J, Belda J, Capilla L, Tallet A, Añón JM, Fernández RL et al (2020) Dexamethasone treatment for the acute respiratory distress syndrome: a multicentre, randomised controlled trial. Lancet Respir Med 8(3):267-276. https://doi.org/10.1016/S22132600(19)30417-5

32. Alijotas-Reig J, Esteve-Valverde E, Belizna C, Selva-O'Callaghan A, Pardos-Gea J, Quintana A, Mekinian A, Anunciacion-Llunell A, Miró-Mur F (2020) Immunomodulatory therapy for the management of severe COVID-19. Beyond the anti-viral therapy: a comprehensive review. Autoimmun Rev 19(7):102569. https://doi. org/10.1016/j.autrev.2020.102569

33. Jiang S, Liu T, Hu Y, Li R, Di X, Jin X, Wang Y, Wang K (2019) Efficacy and safety of glucocorticoids in the treatment of severe community-acquired pneumonia: a meta-analysis. Medicine 98(26):e16239. https://doi.org/10.1097/MD.0000000000016239

34. Annane D, Bellissant E, Bollaert PE, Briegel J, Keh D, Kupfer Y (2015) Corticosteroids for treating sepsis. Cochrane Database Syst Rev. https://doi.org/10.1002/14651858.CD002243.pub3 
35. Annane D, Bellissant E, Bollaert PE, Briegel J, Confalonieri M, De Gaudio R, Keh D, Kupfer Y, Oppert M, Meduri GU (2009) Corticosteroids in the treatment of severe sepsis and septic shock in adults: a systematic review. JAMA 301(22):2362-2375. https:// doi.org/10.1001/jama.2009.815

36. Dale DC, Petersdorf RG (1973) Corticosteroids and infectious diseases. Med Clin N Am 57(5):1277-1287. https://doi.org/10. 1016/s0025-7125(16)32228-3

37. van Paassen J, Vos JS, Hoekstra EM, Neumann K, Boot PC, Arbous SM (2020) Corticosteroid use in COVID-19 patients: a systematic review and meta-analysis on clinical outcomes. Crit Care (London, England) 24(1):696. https://doi.org/10.1186/ s13054-020-03400-9

38. Chroboczek T, Lacoste M, Wackenheim C, Challan-Belval T, Amar B, Boisson T et al (2020) Beneficial effect of corticosteroids in severe COVID-19 pneumonia: a propensity score matching analysis. MedRxiv. https://doi.org/10.1101/2020.05.08.20094755

39. Fusina F, Albani F, Granato E, Meloni A, Rozzini R, Sabatini T, Stellini R, Terragnoli P, Rosano A, Abu Hilal M, Natalini G (2021) Effect of corticosteroids on mortality in hospitalized COVID-19 patients not receiving invasive mechanical ventilation. Clin Pharmacol Ther 109(6):1660-1667. https://doi.org/10.1002/ cpt.2245

40 Wang Y, Jiang W, He Q, Wang C, Wang B, Zhou P et al (2020) Early, low-dose and short-term application of corticosteroid treatment in patients with severe COVID-19 pneumonia: single-center experience from Wuhan, China. MedRxiv. https://doi.org/10. 1101/2020.03.06.20032342

41. WHO Rapid Evidence Appraisal for COVID-19 Therapies (REACT) Working Group, Sterne J, Murthy S, Diaz JV, Slutsky AS, Villar J, Angus DC, Annane D, Azevedo L, Berwanger O, Cavalcanti AB, Dequin PF, Du B, Emberson J, Fisher D, Giraudeau B, Gordon AC, Granholm A, Green C, Haynes R et al (2020) Association between administration of systemic corticosteroids and mortality among critically ill patients with COVID-19: a meta-analysis. JAMA 324(13):1330-1341. https://doi.org/10. 1001/jama.2020.17023

42. Ding C, Feng X, Chen Y, Yuan J, Yi P, Li Y et al (2020) Effect of corticosteroid therapy on the duration of SARS-CoV-2 clearance in patients with mild COVID-19: a retrospective cohort study. Infect Dis Ther 9(4):943-952. https://doi.org/10.1007/ s40121-020-00337-y

43. Wang J, Yang W, Chen P, Guo J, Liu R, Wen P, Li K, Lu Y, Ma T, Li X, Qin S, Zhang Y, Wang Y (2021) The proportion and effect of corticosteroid therapy in patients with COVID-19 infection: a systematic review and meta-analysis. PLoS ONE 16(4):e0249481. https://doi.org/10.1371/journal.pone.0249481

44. Ho KS, Narasimhan B, Difabrizio L, Rogers L, Bose S, Li L, Chen R, Sheehan J, El-Halabi MA, Sarosky K, Wang Z, Eisenberg E, Powell C, Steiger D (2021) Impact of corticosteroids in hospitalised COVID-19 patients. BMJ Open Respir Res 8(1):e000766. https://doi.org/10.1136/bmjresp-2020-000766

45. RECOVERY Collaborative Group, Horby P, Lim WS, Emberson JR, Mafham M, Bell JL, Linsell L, Staplin N, Brightling C, Ustianowski A, Elmahi E, Prudon B, Green C, Felton T, Chadwick D, Rege K, Fegan C, Chappell LC, Faust SN, Jaki T et al (2021) Dexamethasone in hospitalized patients with Covid-19. N Engl J Med 384(8):693-704. https://doi.org/10.1056/NEJMo a2021436

46. Russell B, Moss C, Rigg A, Van Hemelrijck M (2020) COVID19 and treatment with NSAIDs and corticosteroids: should we be limiting their use in the clinical setting? Ecancermedicalscience 14:1023. https://doi.org/10.3332/ecancer.2020.1023

47. Chu CM, Cheng VC, Hung IF, Wong MM, Chan KH, Chan KS, Kao RY, Poon LL, Wong CL, Guan Y, Peiris JS, Yuen KY, HKU/
UCH SARS Study Group (2004) Role of lopinavir/ritonavir in the treatment of SARS: initial virological and clinical findings. Tho$\operatorname{rax} 59(3): 252-256$. https://doi.org/10.1136/thorax.2003.012658

48. Zha L, Li S, Pan L, Tefsen B, Li Y, French N, Chen L, Yang G, Villanueva EV (2020) Corticosteroid treatment of patients with coronavirus disease 2019 (COVID-19). Med J Aust 212(9):416420. https://doi.org/10.5694/mja2.50577

49. Albani F, Fusina F, Granato E, Capotosto C, Ceracchi C, Gargaruti $R$ et al (2020) Effect of corticosteroid treatment on 1376 hospitalized COVID-19 patients. A cohort study. medRxiv. https://doi.org/ 10.1101/2020.07.17.20155994

50 Budhathoki P, Shrestha DB, Rawal E, Khadka S (2020) Corticosteroids in COVID-19: is it rational? A systematic review and meta-analysis. SN Compr Clin Med. https://doi.org/10.1007/ s42399-020-00515-6 (Advance online publication)

51. Sarkar S, Khanna P, Soni KD (2021) Are the steroids a blanket solution for COVID-19? A systematic review and meta-analysis. J Med Virol 93(3):1538-1547. https://doi.org/10.1002/jmv.26483

52. Lu X, Chen T, Wang Y, Wang J, Yan F (2020) Adjuvant corticosteroid therapy for critically ill patients with COVID-19. Crit Care (London, England) 24(1):241. https://doi.org/10.1186/ s13054-020-02964-w

53. Arabi YM, Mandourah Y, Al-Hameed F, Sindi AA, Almekhlafi GA, Hussein MA, Jose J, Pinto R, Al-Omari A, Kharaba A, Almotairi A, Al Khatib K, Alraddadi B, Shalhoub S, Abdulmomen A, Qushmaq I, Mady A, Solaiman O, Al-Aithan AM, Al-Raddadi R et al (2018) Corticosteroid therapy for critically ill patients with middle east respiratory syndrome. Am J Respir Crit Care Med 197(6):757-767. https://doi.org/10.1164/rccm.201706-1172OC

54. Zhang L, Yan X, Fan Q, Liu H, Liu X, Liu Z, Zhang Z (2020) D-dimer levels on admission to predict in-hospital mortality in patients with Covid-19. J Thromb Haemost 18(6):1324-1329. https://doi.org/10.1111/jth.14859

55. Zhou F, Yu T, Du R, Fan G, Liu Y, Liu Z, Xiang J, Wang Y, Song B, Gu X, Guan L, Wei Y, Li H, Wu X, Xu J, Tu S, Zhang Y, Chen $\mathrm{H}$, Cao B (2020) Clinical course and risk factors for mortality of adult inpatients with COVID-19 in Wuhan, China: a retrospective cohort study. Lancet (London, England) 395(10229):1054-1062. https://doi.org/10.1016/S0140-6736(20)30566-3

56. Ronchetti S, Ricci E, Migliorati G, Gentili M, Riccardi C (2018) How glucocorticoids affect the neutrophil life. Int J Mol Sci 19(12):4090. https://doi.org/10.3390/ijms 19124090

57. Imtiaz F, Shafique K, Mirza SS, Ayoob Z, Vart P, Rao S (2012) Neutrophil lymphocyte ratio as a measure of systemic inflammation in prevalent chronic diseases in Asian population. Int Arch Med 5(1):2. https://doi.org/10.1186/1755-7682-5-2

58. Lorente D, Mateo J, Templeton AJ, Zafeiriou Z, Bianchini D, Ferraldeschi R, Bahl A, Shen L, Su Z, Sartor O, de Bono JS (2015) Baseline neutrophil-lymphocyte ratio (NLR) is associated with survival and response to treatment with second-line chemotherapy for advanced prostate cancer independent of baseline steroid use. Ann Oncol 26(4):750-755. https://doi.org/10.1093/annonc/ mdu587

59. Cataudella E, Giraffa CM, Di Marca S, Pulvirenti A, Alaimo S, Pisano M, Terranova V, Corriere T, Ronsisvalle ML, Di Quattro R, Stancanelli B, Giordano M, Vancheri C, Malatino L (2017) Neutrophil-to-lymphocyte ratio: an emerging marker predicting prognosis in elderly adults with community-acquired pneumonia. J Am Geriatr Soc 65(8):1796-1801. https://doi.org/10.1111/jgs. 14894

60. Fekkar A, Poignon C, Blaize M, Lampros A (2020) Fungal infection during COVID-19: does Aspergillus mean secondary invasive aspergillosis? Am J Respir Crit Care Med 202(6):902-903. https:// doi.org/10.1164/rccm.202005-1945LE 
61. van Raalte DH, Diamant M (2014) Steroid diabetes: from mechanism to treatment? Neth J Med 72(2):62-72

62. Fathallah N, Slim R, Larif S, Hmouda H, Ben Salem C (2015) Drug-induced hyperglycaemia and diabetes. Drug Saf 38(12):1153-1168. https://doi.org/10.1007/s40264-015-0339-z

63. Mills E, Devendra S (2015) Steroid-induced hyperglycaemia in primary care. Lond J Prim Care 7(5):103-106. https://doi.org/10. 1080/17571472.2015.1082344

64. Suh S, Park MK (2017) Glucocorticoid-induced diabetes mellitus: an important but overlooked problem. Endocrinol Metab (Seoul, Korea) 32(2):180-189. https://doi.org/10.3803/EnM.2017.32.2. 180

65. Liu XX, Zhu XM, Miao Q, Ye HY, Zhang ZY, Li YM (2014) Hyperglycemia induced by glucocorticoids in nondiabetic patients: a meta-analysis. Ann Nutr Metab 65(4):324-332. https:// doi.org/10.1159/000365892

66. Hwang JL, Weiss RE (2014) Steroid-induced diabetes: a clinical and molecular approach to understanding and treatment. Diabetes Metab Res Rev 30(2):96-102. https://doi.org/10.1002/dmrr.2486

67. van Raalte DH, Ouwens DM, Diamant M (2009) Novel insights into glucocorticoid-mediated diabetogenic effects: towards expansion of therapeutic options? Eur J Clin Investig 39(2):81-93. https://doi.org/10.1111/j.1365-2362.2008.02067.x

68. Sakoda H, Ogihara T, Anai M, Funaki M, Inukai K, Katagiri H, Fukushima Y, Onishi Y, Ono H, Fujishiro M, Kikuchi M, Oka Y, Asano T (2000) Dexamethasone-induced insulin resistance in 3T3-L1 adipocytes is due to inhibition of glucose transport rather than insulin signal transduction. Diabetes 49(10):1700-1708. https://doi.org/10.2337/diabetes.49.10.1700

69. Vegiopoulos A, Herzig S (2007) Glucocorticoids, metabolism and metabolic diseases. Mol Cell Endocrinol 275(1-2):43-61. https:// doi.org/10.1016/j.mce.2007.05.015

70. Boden G, Shulman GI (2002) Free fatty acids in obesity and type 2 diabetes: defining their role in the development of insulin resistance and beta-cell dysfunction. Eur J Clin Investig 32(Suppl 3):14-23. https://doi.org/10.1046/j.1365-2362.32.s3.3.x

71. Delaunay F, Khan A, Cintra A, Davani B, Ling ZC, Andersson A, Ostenson CG, Gustafsson J, Efendic S, Okret S (1997) Pancreatic beta cells are important targets for the diabetogenic effects of glucocorticoids. J Clin Investig 100(8):2094-2098. https://doi.org/10. 1172/JCI119743

72. Pereira RM, Freire de Carvalho J (2011) Glucocorticoid-induced myopathy. Joint Bone Spine 78(1):41-44. https://doi.org/10. 1016/j.jbspin.2010.02.025

73. Schakman O, Gilson H, Thissen JP (2008) Mechanisms of glucocorticoid-induced myopathy. J Endocrinol 197(1):1-10. https:// doi.org/10.1677/JOE-07-0606

74. Gupta A, Gupta Y (2013) Glucocorticoid-induced myopathy: pathophysiology, diagnosis, and treatment. Indian J Endocrinol Metab 17(5):913-916. https://doi.org/10.4103/2230-8210.117215

75. Mitsui $T$, Azuma $H$, Nagasawa M, Iuchi $T$, Akaike M, Odomi M, Matsumoto T (2002) Chronic corticosteroid administration causes mitochondrial dysfunction in skeletal muscle. J Neurol 249(8):1004-1009. https://doi.org/10.1007/s00415-002-0774-5

76. Zhang B, Zhang S (2020) Corticosteroid-induced osteonecrosis in COVID-19: a call for caution. J Bone Miner Res 35(9):18281829. https://doi.org/10.1002/jbmr.4136

77. Griffith JF, Antonio GE, Kumta SM, Hui DS, Wong JK, Joynt GM, Wu AK, Cheung AY, Chiu KH, Chan KM, Leung PC, Ahuja AT (2005) Osteonecrosis of hip and knee in patients with severe acute respiratory syndrome treated with steroids. Radiology 235(1):168-175. https://doi.org/10.1148/radiol.2351040100

78 Guo KJ, Zhao FC, Guo Y, Li FL, Zhu L, Zheng W (2014) The influence of age, gender and treatment with steroids on the incidence of osteonecrosis of the femoral head during the management of severe acute respiratory syndrome: a retrospective study. Bone Joint J 96-B(2):259-262. https://doi.org/10.1302/0301-620X. 96B2.31935

79. Elmantaser M, Stewart G, Young D, Duncan R, Gibson B, Ahmed SF (2010) Skeletal morbidity in children receiving chemotherapy for acute lymphoblastic leukaemia. Arch Dis Child 95(10):805809. https://doi.org/10.1136/adc.2009.172528

80. Weinstein RS (2012) Glucocorticoid-induced osteonecrosis. Endocrine 41(2):183-190. https://doi.org/10.1007/s12020-011-9580-0

81. Mahase E (2020) Covid-19: low dose steroid cuts death in ventilated patients by one third, trial finds. BMJ (Clinical Research ed.) 369:m2422. https://doi.org/10.1136/bmj.m2422

82. Fadel R, Morrison AR, Vahia A, Smith ZR, Chaudhry Z, Bhargava P, Miller J, Kenney RM, Alangaden G, Ramesh MS, Henry Ford COVID-19 Management Task Force (2020) Early shortcourse corticosteroids in hospitalized patients with COVID-19. Clin Infect Dis 71(16):2114-2120. https://doi.org/10.1093/cid/ ciaa601

83. Roncon L, Zuin M, Zuliani G, Rigatelli G (2021) Corticosteroid therapy in COVID-19 patients: don't forget venous thromboembolism. Anaesth Crit Care Pain Med 40(1):100783. https://doi. org/10.1016/j.accpm.2020.11.003

84. Rafiee MJ, Babaki Fard F, Friedrich MG (2020) COVID-19, myocardial edema and dexamethasone. Med Hypotheses 145:110307. https://doi.org/10.1016/j.mehy.2020.110307

85. Andreakos E, Papadaki M, Serhan CN (2021) Dexamethasone, pro-resolving lipid mediators and resolution of inflammation in COVID-19. Allergy 76(3):626-628. https://doi.org/10.1111/all. 14595

86. Angus DC, Derde L, Al-Beidh F, Annane D, Arabi Y, Beane A, van Bentum-Puijk W, Berry L, Bhimani Z, Bonten M, Bradbury C, Brunkhorst F, Buxton M, Buzgau A, Cheng AC, de Jong M, Detry M, Estcourt L, Fitzgerald M, Goossens H et al (2020) Effect of hydrocortisone on mortality and organ support in patients with severe COVID-19: the REMAP-CAP COVID-19 corticosteroid domain randomized clinical trial. JAMA 324(13):1317-1329. https://doi.org/10.1001/jama.2020.17022

87. Dequin PF, Heming N, Meziani F, Plantefève G, Voiriot G, Badié J, François B, Aubron C, Ricard JD, Ehrmann S, Jouan Y, Guillon A, Leclerc M, Coffre C, Bourgoin H, Lengellé C, Caille-Fénérol C, Tavernier E, Zohar S, Giraudeau B et al (2020) Effect of hydrocortisone on 21-day mortality or respiratory support among critically ill patients with COVID-19: a randomized clinical trial. JAMA 324(13):1298-1306. https://doi.org/10.1001/jama.2020. 16761

88. Lee DT, Wing YK, Leung HC, Sung JJ, Ng YK, Yiu GC, Chen RY, Chiu HF (2004) Factors associated with psychosis among patients with severe acute respiratory syndrome: a case-control study. Clin Infect Dis 39(8):1247-1249. https://doi.org/10.1086/ 424016

89. Lee N, Allen Chan KC, Hui DS, Ng EK, Wu A, Chiu RW, Wong VW, Chan PK, Wong KT, Wong E, Cockram CS, Tam JS, Sung JJ, Lo YM (2004) Effects of early corticosteroid treatment on plasma SARS-associated Coronavirus RNA concentrations in adult patients. J Clin Virol 31(4):304-309. https://doi.org/10. 1016/j.jcv.2004.07.006

90. Shah SK, Gecys GT (2006) Prednisone-induced osteoporosis: an overlooked and undertreated adverse effect. J Am Osteopath Assoc 106(11):653-657

91. Wang K, Tan F, Zhou R, Liu D, Ni Z, Liu J, Luo F (2020) Therapeutic response to corticosteroids in a critically ill patient with COVID-19: a case report. Medicine 99(31):e21597. https://doi. org/10.1097/MD.0000000000021597

92. Monreal E, Sainz de la Maza S, Natera-Villalba E, Beltrán-Corbellini Á, Rodríguez-Jorge F, Fernández-Velasco JI, Walo-Delgado 
P, Muriel A, Zamora J, Alonso-Canovas A, Fortún J, Manzano L, Montero-Errasquín B, Costa-Frossard L, Masjuan J, Villar LM, COVID-HRC group (2021) High versus standard doses of corticosteroids in severe COVID-19: a retrospective cohort study. Eur J Clin Microbiol Infect Dis 40(4):761-769. https://doi.org/10.1007/ s10096-020-04078-1

93. Burugu HR, Kandi V, Kutikuppala L, Suvvari TK (2020) Activities of serum ferritin and treatment outcomes among COVID-19 patients treated with vitamin $\mathrm{C}$ and dexamethasone: an uncontrolled single-center observational study. Cureus 12(11):e11442. https://doi.org/10.7759/cureus.11442

94. La Rosée P, Horne A, Hines M, von Bahr Greenwood T, Machowicz R, Berliner N, Birndt S, Gil-Herrera J, Girschikofsky M, Jordan MB, Kumar A, van Laar J, Lachmann G, Nichols KE, Ramanan AV, Wang Y, Wang Z, Janka G, Henter JI (2019) Recommendations for the management of hemophagocytic lymphohistiocytosis in adults. Blood 133(23):2465-2477. https://doi.org/ 10.1182/blood.2018894618

95. Russell CD, Millar JE, Baillie JK (2020) Clinical evidence does not support corticosteroid treatment for 2019-nCoV lung injury. Lancet (London, England) 395(10223):473-475. https://doi.org/ $10.1016 /$ S0140-6736(20)30317-2
96. Soy M, Keser G, Atagündüz P, Tabak F, Atagündüz I, Kayhan S (2020) Cytokine storm in COVID-19: pathogenesis and overview of anti-inflammatory agents used in treatment. Clin Rheumatol 39(7):2085-2094. https://doi.org/10.1007/s10067-020-05190-5

97. Abdolahi N, Kaheh E, Golsha R et al (2020) Letter to the editor: efficacy of different methods of combination regimen administrations including dexamethasone, intravenous immunoglobulin, and interferon-beta to treat critically ill COVID-19 patients: a structured summary of a study protocol for a randomized controlled trial. Trials 21:549. https://doi.org/10.1186/s13063-020-04499-5

98. Matera MG, Rogliani P, Calzetta L, Cazzola M (2020) Pharmacological management of COVID-19 patients with ARDS (CARDS): a narrative review. Respir Med 171:106114. https://doi.org/10. 1016/j.rmed.2020.106114

Publisher's Note Springer Nature remains neutral with regard to jurisdictional claims in published maps and institutional affiliations. 